\title{
Analysis on the Effect of Marketing Strategy Literacy towards MSME's Marketing Performance in Depok, West Java
}

\author{
Anastasia Bernadin Dwi Mardiatmi and Dahlia Pinem
}

\section{ABSTRACT}

\begin{abstract}
Micro, Small, and Medium-sized Enterprise (MSME) owners in Depok, West Java, have yet to apply good marketing strategies. Thus, marketing management literacy needs to be done. This research was intended to analyze and understand the effect of marketing strategy literacy, which is applied in MSME's in Depok, West Java, towards marketing performance. The sampling technique used in this research was random sampling technique, with the samples being 30 MSME owners in Depok, West Java. This is an explanatory research, which used Smart PLS analysis tool. The results showed that $\mathbf{R}$ Square's value is $\mathbf{0 . 6 4 3}$. Hypothesis testing revealed that advertising literacy variable affects marketing performance with a path coefficient value of 0.400 ; promotion sales literacy does not affect marketing performance with a path coefficient value of $\mathbf{- 0 . 0 8 8}$; personal sales literacy affects marketing performance with a path coefficient value of 0.641 ; and lastly, online marketing literacy does not affect marketing performance with a path coefficient value of $\mathbf{- 0 . 1 7 7}$.
\end{abstract}

Keywords: Advertising Literacy; Promotion Sales Literacy; Personal Sales Literacy; Online Marketing Literacy; Marketing Performance.

\author{
Submitted : January 24, 2021 \\ Published : March 5, 2021 \\ ISSN: $2507-1076$ \\ DOI: $10.24018 /$ ejbmr.2021.6.2.709 \\ Anastasia Bernadin Dwi Mardiatmi* \\ Faculty of Economics and Business, \\ Pembangunan Nasional Veteran Jakarta \\ University, Indonesia. \\ (e-mail: bernadindwim@ upnvj.ac.id) \\ Dahlia Pinem \\ Faculty of Economics and Business, \\ Pembangunan Nasional Veteran Jakarta \\ University, Indonesia. \\ (e-mail: pinem_dahlia@yahoo.com)
}

*Corresponding Author

\section{INTRODUCTION}

In general, the presence of Micro, Small, and Mediumsized Enterprises (MSME) has become the backbone of a country's economy, especially in developing countries. Their presence has proven to be able to keep the economic gears of a country running and reduce unemployment. Even though MSME owners are limited in some regards, they are still able to compete with large companies. Amidst the economic recession and the looming threat of bankruptcy for a lot of those large companies, MSMEs has shown that they can still stay afloat, which shows their truest strength [1].

In 2017, Indonesian Ministry of Cooperatives and Small and Medium Enterprises reported that MSMEs have a 99.99\% market share (62.9 million units) from the total of all business owners in Indonesia. Whereas large businesses in Indonesia only have 5.400 units or $0.01 \%$ market share. MSMEs can absorb more than half than larger businesses [2].

MSMEs in Depok, West Java, contributes a lot to the people's welfare. Depok's economy ranks third in the gross regional domestic product (GRDP) growth based on constant prices in West Java, with a growth rate of $6.74 \%$ [3].

On average, the people of Depok spend their income on: $40.84 \%$ for foods, including ready-to-eat foods and drinks; and $59.16 \%$ for non-food things such as housing and household items [3]. Depok's Human Development Index (HDI) is 80.82 ( $3^{\text {rd }}$ place in West Java), GRDP growth rate is $6.74 \%$ ( $3^{\text {rd }}$ place in West Java), and sum of poor people is 49.4 thousand people $\left(6^{\text {th }}\right.$ place in West Java) (BPS West Java
Province, 2020). According to that data, MSME in the food and beverages business have promising prospects.

Some MSMEs in Depok still have external weaknesses such as being unable to adapt to the effects of strategic environments, lack of skills in taking business opportunities, and lack of creativity and innovation to anticipate challenges caused by prolonged economic recession. In an organization, product design and ability to compete is vital to bring forth changes and improvement to the MSME's own mechanism so that they can provide their best products/services to their customers in an efficient and effective manner, increase market competitiveness, and stabilize Depok's economy.

Other than the aforementioned problems, there is little to none marketing strategy applied by MSME owners in Depok as a way to grow their business. If their market outreach is limited, the fact that their products are high quality will not help them to stay afloat. Thus, marketing strategies needs to be taught in order to increase their marketing effectiveness [4].

Selling by promoting products is a direct communication with many provocations used by companies to attract and influence customers to buy more products and try out new products [5]. Personal selling can be defined as a form of communication done via personal interaction, phone calls, or other means done to form long-lasting relationship between a company and its customers [6]. Furthermore, it can also be defined as a marketing strategy done in the interaction between a company's marketers and customers in order to attract customers and retain connection with them [7]. 
Online marketing gives marketer opportunity to reach a wide array of audience using well-designed websites, search ads, ads with pictures, and e-mail. Marketer can take advantage of online communities or ask customers to participate in creating the company's marketing assets in the long term. Social media is one such way of marketing communication for a brand [8].

\section{LITERATURE REVIEW}

\section{A. Marketing Performance}

Performance is a result of an effort done either by a person or a team in finishing their task and responsibility in order to fulfill the organization's goals [9]. Whereas, marketing performance is a company's achievement measured by their overall marketing efforts [10]. Furthermore, according to [11], marketing performance is a multidimensional process, which includes three dimensions: effectivity, efficiency, and adaptability. A marketing's effectiveness and efficiency are related to the company's market goals, such as profit, growth, and market share. Marketing performance is a measure for a company to assess the achievement of a predetermined strategy. The achievement of marketing performance can be seen from the indication of increasing sales volume, increasing operating profit, and increasing customers [12]. Marketing performance is a factor commonly used to measure the impact of a corporate strategy. The company's strategy is always directed at producing performance in the form of both marketing performance and financial performance [13].

\section{B. Advertising Literacy}

Advertisement is a placement of an announcement and persuasive messages in a time/place in a mass media that has been bought by companies, businesses, nonprofit organizations, governmental bodies, and any individual person in their pursuit to inform/persuade their target market/audience regarding a product, service, organization, or an idea [7]. Furthermore, [14] stated that an advertisement is a means of communication regarding a product, delivered by many forms of media by the initiator so that the public agrees with it and follows it. Advertising literacy is the ability to recognize, evaluate, and understand advertisements and other commercial messages [15]. Then advertising literacy is given so that consumers can understand the message and agree or disagree with what is conveyed by the producer through the advertisement, even memorizing the jingle or jargon of the advertising product.

\section{Promotion Sales Literacy}

Sales promotion is all activity intended to increase the volume of goods and services from producer to the marketer. Sales promotion points include brochures and information pamphlets, among other things [16]. Furthermore, sales promotion is a term used to describe its own activities, which complements sales and advertising, making them run more efficiently. For example, shows, exhibitions, demos, and other means of sales which are not done repetitively and is not an ordinary thing [17]. Sales promotion is an activity or material that offers customers, sales personnel, or resellers a direct inducement for purchasing a product. This inducement, which adds value to or incentive for the product, might take the form of coupon, sweepstakes, or refund [18].

\section{Personal Sales Literacy}

Personal sales, as a part of a company's marketing strategy, is a concrete way to make direct sales so that they can understand which products or services the customers are quick to respond to [17]. There are three characteristics of personal sales: personal confrontation is a lively, direct, and interactive relationship between two or more people; cultivation is a trait which allows the development of a relationship, ranging from strictly business to a more friendly one; and lastly, responses is a situation as if in which, the customers must listen, pay attention, and respond [19]. In addition, personal selling is a face-to-face interaction with one or more prospective buyers for the purpose of making presentations, answering questions, or procuring messages.

\section{E. Online Marketing Literacy}

Online marketing is an activity and online programs designed to involve customers and, both directly and indirectly, increase brand awareness and sales of a product or service [8]. Social media is a medium of communication that users can use to interact and share knowledge in a wide scale. Some of the more popular social medias are Facebook, Twitter, LINE, YouTube, etc. Online marketing cannot only be done using social media, but also marketplaces.

\section{F. Literacy}

Literacy is to access, analyze, evaluate, and communicate messages in various forms [20]. Promotion literacy is related to understanding the logic of product placement, media content containing brands, sponsorship, and publicity in certain events.

This research's hypotheses are as following:

$\mathrm{H}_{1}$ : Advertising literacy affects marketing performance in MSMEs in Depok, West Java.

$\mathrm{H}_{2}$ : Promotion sales literacy affects marketing performance in MSMEs in Depok, West Java.

$\mathrm{H}_{3}$ : Personal Sales literacy affects marketing performance in MSMEs in Depok, West Java.

$\mathrm{H}_{4}$ : Online marketing literacy affects marketing performance in MSMEs in Depok, West Java.

\section{Research Methodology}

This research was an explanatory research with the goal of explaining the connection between variables using hypothesis testing with quantitative data gathered from the primary sources of Likert Scale questionnaires given to 30 MSME owners in Depok. Sampling technique was random sampling and analysis was done with the help of the Smart PLS software. 
TABLE 1: INSTRUMENT GRILLE

\begin{tabular}{cl}
\hline \multicolumn{1}{c}{ Variables } & \multicolumn{1}{c}{ Indicators } \\
\hline & Increase Sales Volume \\
Marketing Performance $(\mathrm{Y})$ & Increase Profit \\
& Increase Customer \\
& Increase Sales Volume \\
& Television \\
& News Paper \\
Advertising Literacy $\left(\mathrm{X}_{1}\right)$ & Magazine \\
& Outdoor \\
& Coupon \\
Promotion Sales Literacy $\left(\mathrm{X}_{2}\right)$ & Premium \\
& Product Sample \\
& Lottery \\
& Sales Presentation \\
& Incentive Program \\
Personal Sales Literacy $\left(\mathrm{X}_{3}\right)$ & Trade Show \\
& Website \\
Online Marketing Literacy $\left(\mathrm{X}_{4}\right)$ & Online Community \\
& Social Media \\
\hline
\end{tabular}

\section{RESUlT AND DisCUSSIONS}

Based on the Smart PLS output, the outer model in this study is shown in the image below:

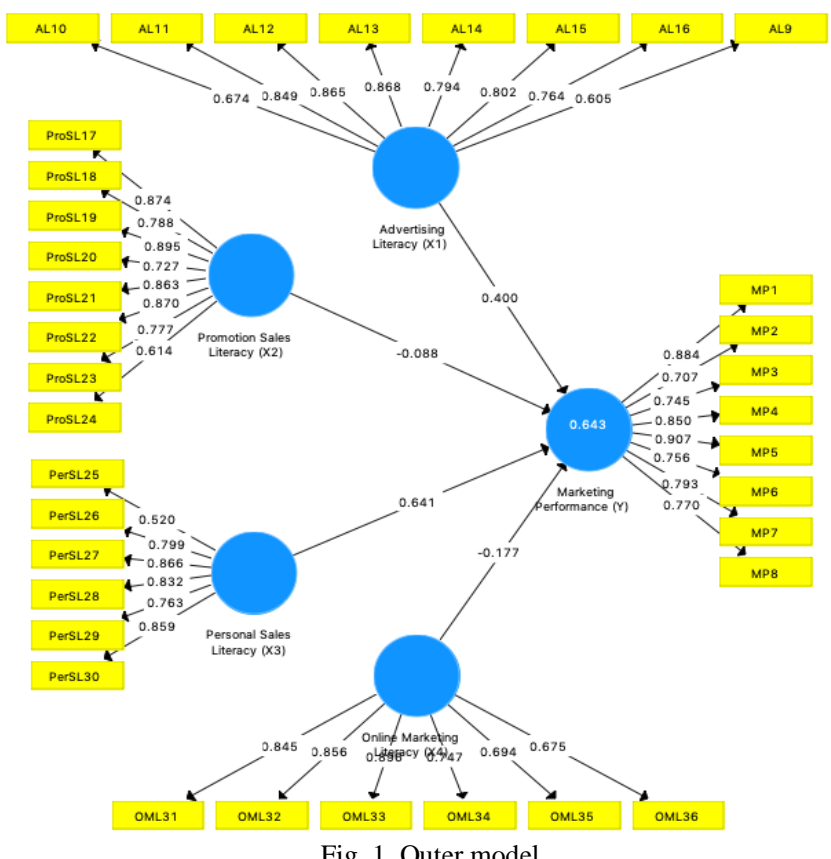

From Smart PLS's output, statements with a score of $>0.5$ was deemed valid and $>0.7$ was deemed reliable. All statements used in this research had already been verified to be valid and reliable. R-Square value was at 0.643 , meaning that the total contribution of advertising, sales promotion, personal sales, and online marketing literacy variables towards marketing performance is $64.3 \%$.

After each statement was deemed valid and reliable, they were tested with hypotheses test.

TABLE 2: HYPOTHESIS TEST

\begin{tabular}{|c|c|c|c|}
\hline & $\begin{array}{c}\text { Original } \\
\text { Sample }(\mathrm{O}\end{array}$ & $\begin{array}{c}\text { Statistic-T } \\
(|\mathrm{O} / \mathrm{STDEV}|)\end{array}$ & $\begin{array}{c}\mathrm{P} \\
\text { Values }\end{array}$ \\
\hline $\begin{array}{l}\text { Advertising Literacy }\left(\mathrm{X}_{1}\right) \\
\text { Marketing Performance }(\mathrm{Y})\end{array}$ & 0.400 & 1.975 & 0.049 \\
\hline $\begin{array}{l}\text { Promotion Sales Literacy }\left(\mathrm{X}_{2}\right) \text {-> } \\
\text { Marketing Performance }(\mathrm{Y})\end{array}$ & -0.088 & 0.385 & 0.700 \\
\hline $\begin{array}{l}\text { Personal Sales Literacy }\left(\mathrm{X}_{3}\right)-> \\
\text { Marketing Performance }(\mathrm{Y})\end{array}$ & 0.641 & 2.477 & 0.014 \\
\hline $\begin{array}{l}\text { Online Marketing Literacy }\left(\mathrm{X}_{4}\right) \text { - } \\
\text { > Marketing Performance }(\mathrm{Y})\end{array}$ & -0.177 & 0.592 & 0.554 \\
\hline
\end{tabular}

From the test, the results stated that the advertising literacy variable affects marketing performance, shown by the coefficient value of 0.400 . Hypothesis test results showed that the value of $t_{\text {count }} 1.975>t_{\text {table }} 1.708$ and significant value of $0.049<0.05$. In other words, $\mathrm{H}_{1}$ was accepted. Thus, because that hypothesis was accepted, it could be inferred that if advertising literacy were increased by $1 \%$, marketing performance would increase by $40 \%$. This means that advertising literacy has quite a large effect in increasing Depok MSME owners' marketing performance. Advertising via newspapers, TV, magazines, and outdoor plaques can attract customers to buy the advertised product. Eye-catching advertising can increase the consumer's demand of the product, and thus each purchase can increase the selling volume [21].

Furthermore, promotion sales literacy did not affect marketing performance, as shown by the path coefficient value of -0.088 , and the values of $\mathrm{t}_{\text {count }} 0.385<\mathrm{t}_{\text {table }} 1.708$ and $\mathrm{P}$ value of $0.700>0.05$, meaning that $\mathrm{H}_{2}$ was rejected. Promotion sales literacy that was done could hardly increase marketing performance. MSME owners did have difficulties in aligning to their sales promotion strategies, such as giving out shopping coupons or lotteries, because they lacked capital [22].

Personal sales literacy affects marketing performance. This was shown by the path coefficient value of 0.641 , value of $\mathrm{t}_{\text {count }} 2.477>\mathrm{t}_{\text {table }} 1,708$, and $\mathrm{P}$ value of $0.014<0.05$. In other words, $\mathrm{H}_{3}$ was accepted. If personal sales literacy increased by $1 \%$, MSME's marketing performance would increase by $64.1 \%$. MSME owners in Depok agreed that personal sales literacy was an effective way to increase their marketing performance. An example of one event which affected it the most was their participation in a trade show, because such events gave chance for MSMEs to promote their products directly to customers [23], [24].

Online marketing literacy did not affect marketing performance, as shown by its path coefficient value of -0.177 , the value of $\mathrm{t}_{\text {count }} 0,592<\mathrm{t}_{\text {table }} 1,708$, and $\mathrm{P}$ value of $0.554>$ 0,05 . In other words, $\mathrm{H}_{4}$ was rejected. Based on the rejection of the fourth hypothesis, it could be inferred that online marketing was not yet able to increase marketing performance of Depok MSMEs. Social media was the only online medium often used to promote, whereas there are two more mediums of equal importance: website and online community. The latter two platforms were yet to be used to their maximum effect by Depok MSMEs. Thus, literacy in online marketing using website and other online platforms helps MSMEs a lot [25], [26]. Other research states that marketing through e-commerce websites and social media can improve marketing performance [27].

\section{CONCLUSIONS AND RECOMMENDATION}

From the results above, advertising, and personal sales literacy is able to increase marketing performance of MSMEs in Depok, West Java. Both of them are deemed effective in increasing marketing performance. Thus, MSME owners in Depok should keep and increase their knowledge and capabilities in marketing their products through advertisement and personal sales. MSME actors must be able to create attractive advertisements using various media. 
Promotion skills through personal selling need to be maintained. However, promotion sales and online marketing literacy is not able to increase marketing performance. Sales promotion literacy is hampered by the MSMEs capital in practice; online marketing literacy is not fully applied because MSME owners in Depok does not fully understand and is not fully able to operate online mediums such as website, online communities, and social media. Thus, MSME owners in Depok should revise their strategies to gain more capital and increase their capabilities in using online mediums to market their products/services.

\section{ACKNOWLEDGEMENTS}

The authors would like to thank to Pembangunan Nasional Veteran Jakarta University for facilitating and funding this research, the Depok City government for giving permission to carry out activities and also respondents who were willing to take the time to become the subject of this research.

\section{REFERENCES}

[1] C. B. Sulistyo, "Pemberdayaan UMKM Menuju Go International," Investor $2020 . \quad$ Daily, [Online]. Available: https://investor.id/opinion/pemberdayaan-umkm-menuju-gointernational. [Accessed: 24-Jan-2020].

[2] D. M. Haryanti and I. Hidayah, "Potret UMKM Indonesia: Si Kecil yang Berperan Besar.," ukmindonesia.id, 2018.

[3] B. K. Depok, "Kota Depok Dalam Angka," 2020.

[4] A. Kurniawan and M. Asharudin, "Small and Medium Entreprises (SMEs) Faced Digital Marketing," Econ. Bus., vol. 1, no. 2, pp. 1-34, 2016.

[5] H. Kartajaya, Marketing for turnaround: Realizing the network company. Jakarta: Gramedia Pustaka Utama, 2012.

[6] A. Setyaningrum, Prinsip-Prinsip Pemasaran. Yogyakarta: Andi, 2015.

[7] P. Kotler and G. Armstrong, Principles of Marketing, 16 Edition. London: Pearson Education, Inc, 2016.

[8] P. Kotler and K. Keller, Marketing Management. England: Pearson, 2016.

[9] I. K. Dewi and A. Mashar, Nilai-Nilai Profetik Dalam Kepemimpinan Modern Pada Manajemen Kinerja. Yogyakarta: CV GRE Publishing, 2019.

[10] S. F. Hidayatullah and R. G. Patalo, "Entrepreneural Marketing: Peningkatan Kinerja Pemasaran Dengan Entrepreneural Marketing dan Keunggulan Bersaing.," Uwais Inspirasi Indonesia, Jawa Timur, 2019.

[11] Yuhui, "Measuring Marketing Performance: A Review and a Framework," Mark. Rev., vol. 10, no. 1, pp. 25-40, 2010.

[12] Moeheriono, Pengukuran Kinerja Berbasis Kompetensi. Jakarta: Rajawali Pers, 2012.

[13] A. . Ferdinand, Structural Equation Modelling dalam Penelitian Manajemen. Semarang: BP-UNDIP, 2002.

[14] Pujiyanto, Periklanan. Malang: Universitas Negeri Malang, 2001.

[15] N. Malmelin, "What is advertising literacy: Exploring the dimensions of the advertising literacy," J. Vis. Lit., vol. 29, no. 2, pp. 129-142, 2010.

[16] R. Lupiyoadi, Manajemen Pemasaran Jasa Berbasis Kompetensi. Jakarta: Salemba Empat, 2013.

[17] B. Alma, Manajemen Pemasaran dan Manajemen Jasa. Bandung: Alfabeta, 2016.

[18] J. P. Peter and J. H. Donnelly, Marketing management: knowledge and skills, 11th ed. Boston: Mcgraw-Hill, 2013.

[19] F. Tjiptono, Strategi Pemasaran, 4th ed. Yogyakarta: Andi Yogyakarta, 2015.

[20] L. Eagle, J. K. Philip, and B. SAndy, "Insights Into Interpreting Integrated Marketing Communication: A Two-Nation Qualitative Comparison," Eouropean J. Mark., 2007.

[21] Nurdin and T. Djuhartono, "Pengaruh Periklanan Dan Kualitas Produk Terhadap Keputusan Membeli Handphone Merek Samsung Pt. Telkomsel," Sosio e-Kons, vol. 11, no. 1, pp. 46-54, 2019.

[22] R. S. Putri and I. Safri, "Pengaruh Promosi Penjualan Dalam Meningkatkan Penjualan,” J. Valuta, vol. 1, no. 2, pp. 298-321, 2015.
[23] N. F. Yudith, “Analisis Distribusi Selling-In Untuk Meningkatkan Kinerja Pemasaran,” Universitas Diponegoro, 2005.

[24] G. Sugiyarti, "Analisis Efektivitas Kegiatan dan Tingkat Pengalaman dalam Meningkatkan Kinerja Pemasaran Tenaga Penjualan dengan Kompetensi Teknik Sebagai Variabel Intervening Pada Usaha Kecil Menengah Pakaian Jadi di Kota Semarang," Media Ekon. dan Manaj., vol. 33, no. 2, pp. 140-148, 2018.

[25] O. A. Adegbuyi, F. A. Akinyele, and S. T. Akinyele, "Effect of Social Media Marketing on Small Scale Business Performance in OtaMetropolis, Nigeria," Int. J. Soc. Sci. Manag., vol. 2, no. 3, pp. 275283, 2015.

[26] K. Aswar and Ermawati, "Determination Cost of Sales and Utilization of Internet Media for SMEs Marketing in Kelanggaran Unyur," Eur. J. Bus. Manag. Res., vol. 5, no. 5, pp. 1-3, 2020.

[27] D. Prihadi and A. D. Susilawati, "Pengaruh Kemampuan E-Commerce dan Promosi di Media Sosial terhadap Kinerja Pemasaraan," Benefit J. Manaj. Dan Bisnis, vol. 3, no. 1, 2018.

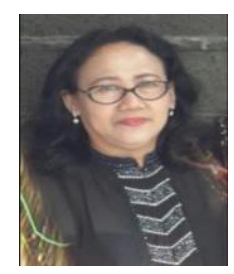

Anastasia Bernadin Dwi Mardiatmi is a lecturer of management in Faculty of Economics and Business at Pembangunan Nasional Veteran Jakarta University, Indonesia. She holds a Masters of Management from IPWI Jakarta University, Indonesia. Her current research interest is in areas of Marketing, MSMEs, and Entrepreneur. She has published a number of papers in various refereed journal and conference proceedings.

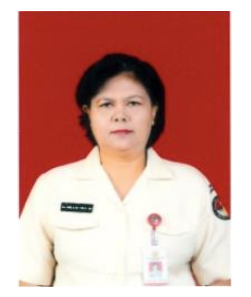

Dahlia Pinem is a lecturer of management in Faculty of Economics and Business at Pembangunan Nasional Veteran Jakarta University, Indonesia. She holds a Masters of Management from Jagakarsa University, Indonesia. Her current research interest is in areas of Finance, Macro Economics and Entrepreneur. She has published a number of papers in various refereed journal and conference proceedings. 